九州大学学術情報リポジトリ

Kyushu University Institutional Repository

\title{
Development of a Motorized Digital Cone Penetrometer
}

Chung, Sun-0k

Department of Biosystems Machinery Engineering, Collage of Agricultural and Life Sciences, Chungnam National University

Cho, Jin-Woong

Department of Crop Science, Collage of Agricultural and Life Sciences, Chungnam National University

Yamakawa, Takeo

Laboratory of Plant Nutrition, Division of Molecular Biosciences, Department of Biosciences \& Biotechnology, Faculty of Agriculture, Kyushu University

https://doi.org/10.5109/25197

出版情報：九州大学大学院農学研究院紀要. 57 (2)，pp. 399-404，2012-09-20. Faculty of Agriculture, Kyushu University

バージョン：

権利関係 : 


\title{
Development of a Motorized Digital Cone Penetrometer
}

\section{Sun-Ok CHUNG ${ }^{1}$, Jin-Woong $\mathrm{CHO}^{2 *}$ and Takeo YAMAKAWA}

\author{
Laboratory of Plant Nutrition, Division of Molecular Biosciences, Department of Biosciences \& \\ Biotechnology, Faculty of Agriculture, Kyushu University, 6-10-1 \\ Hakozaki, Fukuoka 812-8581, Japan \\ (Received April 24, 2012 and accepted May 10, 2012)
}

\begin{abstract}
Quantification and management of variability in soil strength, or soil compaction, is an important issue in countries such as Korea and Japan where typical field sizes are small, but tractor mounted on-the-go sensors that have been developed in USA and European countries are not practical. Therefore, hand-operated digital penetrometers have been widely used in Asian countries, but maintaining standard penetration rate and angle would be difficult. In this study, a motorized digital cone penetrometer that could penetrate up to $50 \mathrm{~cm}$ was developed. The penetrometer was small and light device enough to be transported manually to allow movement on wet-paddy fields and narrow greenhouse inter-rows. The penetrometer included 3 cone tips to reduce data collection time, an electrical motor to push the cone tips into the soil, an encoder to measure penetration depth, a frame and rubber wheels, and a central processing unit to control the motor and log sensor data and differential global poisoning system (DGPS) position. The prototype sensor could detect vertical cone index (CI) variations and peaks similar to a hand-operated commercial unit, but they were less erroneous, represented actual soil strength levels better, and reduced nugget variances significantly, due to a stable penetration rate and angle.
\end{abstract}

Keywords: cone penetrometer, precision agriculture, soil sensor, soil strength

\section{INTRODUCTION}

Precision agriculture (PA) is well established in North America, Europe, and Australia, where production fields are relatively large. PA has also attracted interest and has seen limited adoption in Asian countries including Korea and Japan, where fields are 0.3 to 1.0 ha in size. The potential of PA has been documented by showing within-field variability in site variables such as rice growth and yield, and soil chemical properties (Chung et al., 2000) and cone index (Chung et al., 2006).

Soil compaction caused by management such as wheel traffic of agricultural machinery and/or tillage operations, as well as by natural phenomena such as rainfall and drying, is becoming a greater concern in crop production and the environment (Horn et al., 1995). Soil physical and chemical properties govern the transport of nutrients and water through the soil and the amount of plant available nutrients and water (Barber, 1984). Soil compaction affects physical, biological, and chemical properties of soil, often causing dense layers in soils and negative impacts on crop root growth.

The amount of compaction is influenced by soil properties such as texture and water content, and by management practices. Thus, the degree of compaction could be different among fields, among within-field locations, and/or among different soil horizons due to their specific soil conditions (Koolen and Kuipers, 1983). Therefore, site-specific quantification of horizontal and vertical var-

1 Department of Biosystems Machinery Engineering, Collage of Agricultural and Life Sciences, Chungnam National University, Daejeon, Korea

2 Department of Crop Science, Collage of Agricultural and Life Sciences, Chungnam National University, Daejeon, Korea

* Corresponding author (E-mail: jwcho@cnu.ac.kr) iations in soil compaction is an important part of an overall soil management plan.

The degree of soil compaction, called compactness, traditionally has been determined through laboratory tests of soil samples and expressed as pore space, void ratio, or bulk density (Koolen and Kuipers, 1983). An alternative approach to estimate the state of soil compaction is to measure soil strength, since soil strength is strongly associated with compactness, packing density, relative bulk density, and drainable porosity (Canarache, 1991). Laboratory determination of either soil compactness or soil strength at the spatial resolution needed in PA is time-consuming, laborious, and expensive even if the required, spatially dense sampling is possible.

The main tool used to quantify soil strength with depth and thereby provide information related to soil compaction and morphological characteristics is the cone penetrometer (Mulqueen et al., 1977). The index of soil strength measured by a cone penetrometer, cone index (CI, in $\mathrm{MPa}$ ), is defined as the force per unit base area required to push the penetrometer through a specified small increment of soil according to operational manual. Since readings are taken vertically starting at the soil surface, cone penetrometer readings require a "stop-andgo" procedure with data collected at discrete locations. Because of this, it is laborious and time-consuming to collect enough data with a cone penetrometer to accurately map compaction variations within a field. Also, it is difficult to maintain the standard penetration rate of $30 \mathrm{~mm} / \mathrm{s}$ with a hand-operated penetrometer.

To overcome these limitations of the hand-operated single-tip penetrometer and improve efficiency and reliability in data collection, a number of researchers have attempted "on-the-go" horizontal measurement of "CI-like" soil strength at multiple depths (Chung et al., 
2006; Andrade-Sanchez et al., 2007). Also, hydraulically-powered multiple-tip cone penetrometers mounted on all-terrain-vehicles or tractors have been developed not only in countries where field sizes are relatively large (Raper et al., 1999; Price and Theriot, 2003), but also in Asian countries such as Korea and Japan where common field sizes are 0.3 to 1.0 ha (Lee et al., 2002; Chong et al., 2005).

Although quantification and management of variability in soil strength, or soil compaction, is also an important issue, tractor mounted sensors may not be preferable, due to the small size and condition (e.g., wet-paddy fields, narrow greenhouse inter-rows) of typical fields. Hand-operated single-tip cone penetrometers capable of digital data collection (e.g., at every 5 -cm depth) have been imported and widely used. However, with handoperated penetrometers, it is difficult to maintain the standard constant penetration rate (i.e., $30 \mathrm{~mm} / \mathrm{s}$ ) and to maintain the penetrometer shaft in a vertical orientation during insertion. Therefore, development of a soil strength sensor efficient and suitable for Asian agricultural fields is necessary.

The overall objective of this study was to develop a digital cone penetrometer suitable for small agricultural fields. Specific objectives were to (1) design and construct a motorized multiple-tip cone penetrometer that was small and light enough to be transported manually to allow movement on wet-paddy fields and narrow greenhouse inter-rows, and that could collect CI continuously during penetration, and (2) validate the performance of the penetrometer through measurement and characterization of within-field CI variability, and comparison with a commercial hand-operated digital cone penetrometer.

\section{MATERIALS AND METHODS}

\section{Design and construction}

Maximum sensing depth, expected maximum CI

Maximum sensing depth and expected maximum CI were determined based on variability in CI profile, and depth of restrictive layers (e.g., hardpan) and the crop root zone in wet-paddy and dry upland fields. From investigation of CI profiles collected at different compaction levels in an upland field with claypan soils, Chung et al. (2004) determined a 50-cm sensing depth for an onthe-go soil strength profile sensor since a large portion of CI variation occurred at depths less than about $50 \mathrm{~cm}$, and nutrient uptake by the plant in the early stages of crop growth would take place near the soil surface. In a survey of Korean paddy fields over 16 soil series representing typical rice fields and covering $56 \%$ of the total Korean paddy field area, Kim et al. (2006) reported that maximum CI value, depth to the maximum CI, and depth to the hardpan were $4.2 \mathrm{MPa}, 21.7 \mathrm{~cm}$, and $23 \mathrm{~cm}$, respectively. Taylor and Gardner (1963) showed that CI readings above $2 \mathrm{MPa}$ could significantly impede root growth and reduce crop yields for upland dry fields. Jo et al. (1983) reported that the critical CI for rice paddy soils was about $1 \mathrm{MPa}$. Based on the literature review, we determined maximum sensing depth and expected maxi- mum CI as $50 \mathrm{~cm}$ and $4.2 \mathrm{MPa}$, respectively.

Load cell selection and tip configuration

Load cell selection was based on the size and design of the sensing tip and the expected maximum values of soil resistance. An ASABE standard small cone with a base area of $130 \mathrm{~mm}^{2}$ and a shaft diameter of a $13.83 \mathrm{~mm}$ was selected. Assuming that CI would be less than 4.2 $\mathrm{MPa}$ in most agricultural soils at depths shallower than $50 \mathrm{~cm}$, the maximum expected force was calculated as $4.2 \mathrm{MPa} \times 130 \mathrm{~mm}^{2}=546 \mathrm{~N}$. After a survey of available commercial products, a compression load cell with a diameter of $59 \mathrm{~mm}$ (model CBES, Bonshin Loadcell Co., Seongnam, Korea) was selected. The sensor had a full bridge circuit of foil strain gauges with temperature compensation from -10 to $70^{\circ} \mathrm{C}$. Rated capacity, allowable maximum capacity, and accuracy (combined non-linearity, hysteresis, and non-repeatability) of the load cell were 0 to $1.96 \mathrm{kN}, 0$ to $5.88 \mathrm{kN}$ and better than $5.87 \mathrm{~N}$ ( $0.3 \%$ of full scale), respectively. Corresponding CI values were $15.08 \mathrm{MPa}$, 45.24 $\mathrm{MPa}$ and $0.045 \mathrm{MPa}$, respectively.

We pursued a motorized digital multiple-cone penetrometer light enough for a person to transport and operate. The measurable CI range was dependent on the number of cone tips used and total weight of the penetrometer and a person standing on the frame, as expressed in equation 1. Assuming that weight of a normal adult is $686.7 \mathrm{~N}(70 \mathrm{~kg} \times 9.81)$, required weights of the penetrometer to assure penetration were $-137.34 \mathrm{~N}$ $(-14 \mathrm{~kg}), 402.21 \mathrm{~N}(41 \mathrm{~kg})$, and $951.57 \mathrm{~N}$ (97 kg) for 1, 2, and 3 penetrometer tips, respectively. Considering weight of the battery, motor, frame, and other parts of the penetrometer, we decided to use 3 tips, meaning that the required weight of the penetrometer was $951.57 \mathrm{~N}$. Tip spacing was set at $15 \mathrm{~cm}$ as recommended by the operational manual. When fabricated, the total weight of the penetrometer was about $981 \mathrm{~N}$ (100 kg).

$$
\begin{aligned}
& \text { Number of tips } \times 546(\mathrm{~N}) \\
& =\text { Weight of a normal adult }(70 \mathrm{~kg} \times 9.81) \\
& \quad+\text { Weight of the penetrometer }
\end{aligned}
$$

\section{Motor, frame, and safety measures}

A 12-V, 200-W, DC motor with capacities of $2260 \mathrm{rpm}$ and $27 \mathrm{~A}$ at rated load (model S9D, SPG Co., Incheon, Korea) was chosen. Rotation was transmitted from the motor to a ball screw jack with a 10-mm pitch through a rubber belt and a speed reduction gear (12.5:1) to move the 3-tip penetrometer up and down. The ball screw was centered between two linear motion (LM) guides on which the penetration assembly moved. An incrementaltype rotary encoder with a resolution of $6^{\circ}$ (model E50S8, Autonics, Yangsan, Korea) was mounted on top of the ball screw to measure penetration depth.

Other parts of the sensor were wheels (width: $40 \mathrm{~mm}$, diameter: $500 \mathrm{~mm}$ ), a handle, and a battery (DC $12 \mathrm{~V}$, $100 \mathrm{~A}$ ). Two limit switches, one each at top and bottom of one LM guide, were installed to restrict range of the penetration assembly. To protect the sensor from excessive load, the motor was controlled to stop when meas- 


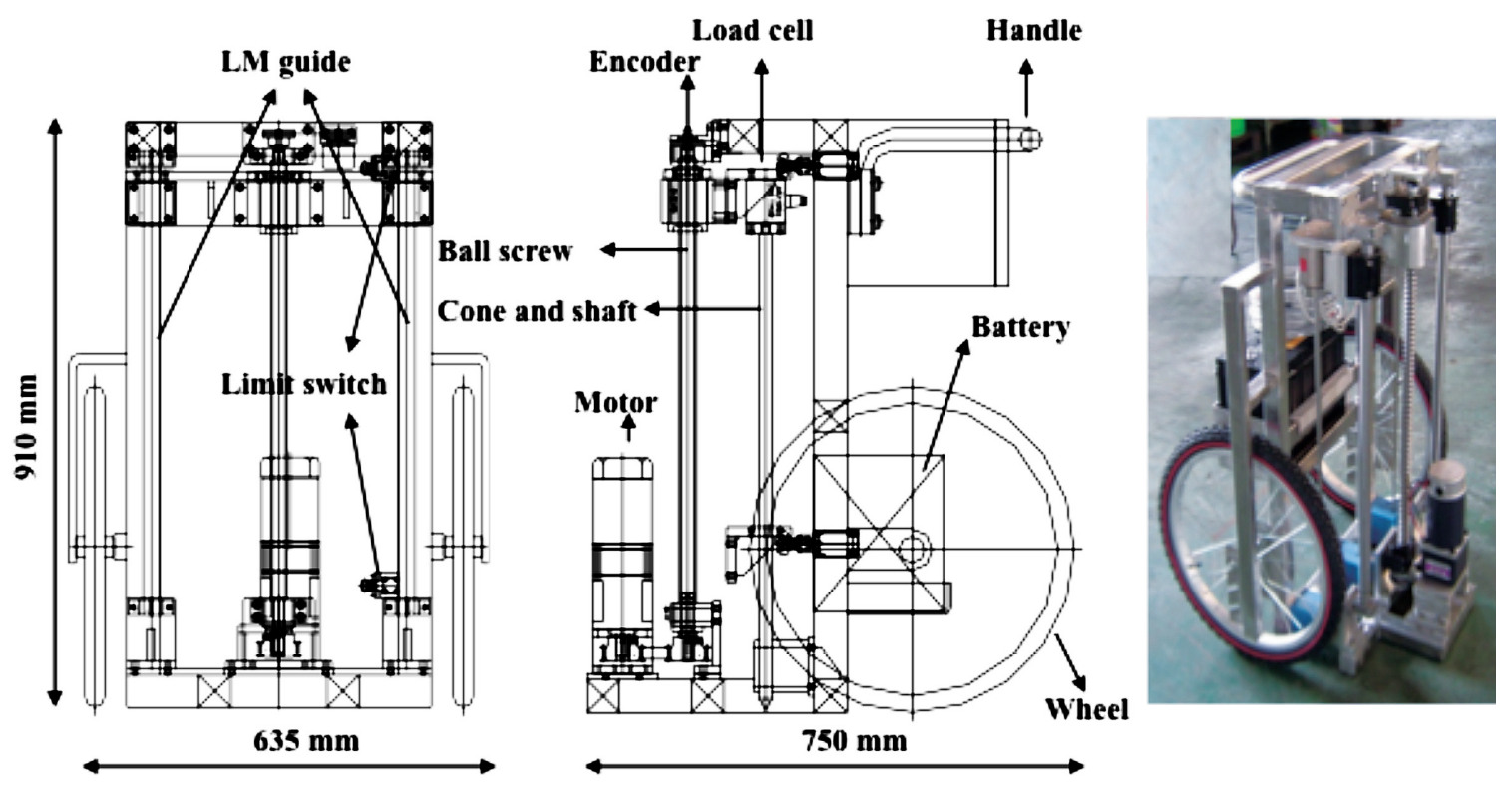

Fig. 1. Drawings (front view: left, side view: center) and a photo (right) of the motorized 3-tip digital penetrometer.

ured CI was greater than a programmed maximum value (e.g., $6 \mathrm{MPa}$ in the study). When constructed, size of the prototype was (height $\times$ width $\times$ thickness: $910 \times 635$ $\times 750 \mathrm{~mm}$ ) during operation, as shown in Fig. 1, and the thickness could be reduced to $500 \mathrm{~mm}$ with disassembly of battery, handle, and wheels, for transportation in a sport utility vehicle (SUV).

\section{Data acquisition}

A data acquisition system to control the motor and collect CI profiles was developed using a micro controller unit (MCU) (model Atmega 2560, Atmel Corporation, San Jose, CA, USA). The unit provided 4 RS-232 channels and 16 analog-to-digital converter channels with 10-bit resolution. Motor speed was set to produce a $30 \mathrm{~mm} / \mathrm{s}$ penetration rate. Signals from the 3 load cells were collected on a 1-cm depth interval determined by the encoder signal, converted to CI values, and saved as a file for each measuring point with DGPS locational information (approx. $15 \mathrm{~cm}$ accuracy) obtained through a MCU RS-232 channel.

Force data for each tip were processed in parallel through a series of data acquisition components. The output of the load cell was $2 \mathrm{mV} \mathrm{V}^{-1}$ at rated load $(1.96 \mathrm{kN})$. A 3.7-V excitation input was used, resulting in a $7.4 \mathrm{mV}$ signal at $1.96 \mathrm{kN}$. The signal from each load cell was sent to the data acquisition system through a transducer amplifier (model S7DC, RDP Electrosense, Inc., Pottstown, PA, USA). The amplifier provided a variable gain, which was set at its maximum value of 1,250 for this application, and low-pass filtering with a $20 \mathrm{~Hz}$ bandwidth. Data from the MCU was saved on a 1-GB secure digital (SD) card.

Using the manufacturer's specifications, the output of the data acquisition system (as a digital number, DN) was transformed to force $(\mathrm{kN})$ and $\mathrm{CI}(\mathrm{MPa})$ :

$$
\text { Force } \begin{aligned}
(\mathrm{kN}) & =\frac{\mathrm{DN}}{R_{d a} \times G_{a m} \times G_{l c} \times V_{i n}} \\
& =2.07 \times 10^{-3} \mathrm{DN}
\end{aligned}
$$

where

$R_{d a}=$ data acquisition system resolution, 1024 counts $(5 \mathrm{~V})^{-1}$

$G_{a m}=$ amplifier gain, 1250

$G_{l c}=$ load cell gain, $2 \times 10^{-3} \mathrm{~V} \mathrm{~V}^{-1}(1.96 \mathrm{kN})^{-1}$

$V_{\text {in }}=$ load cell input voltage, $3.7 \mathrm{~V}$

$$
\begin{aligned}
\mathrm{CI}(\mathrm{MPa})= & \frac{\text { force }(\mathrm{kN}) \times 10^{-3}}{A_{\text {tip }}} \\
& =7.69 \times \text { force }(\mathrm{kN}) \\
& =15.92 \times 10^{-3} \mathrm{DN}
\end{aligned}
$$

where $A_{\text {tip }}$ is the projected area of the sensing tip $\left(1.30 \times 10^{-4} \mathrm{~m}^{2}\right)$.

\section{Experimental design and analytical procedures}

Performance of the prototype was compared with that of a commercial hand-operated single-tip cone penetrometer. The commercial unit (model Investigator Soil Compaction Meter, Spectrum Technologies, Inc., EastPlainfield, IL, USA; Fig. 2, bottom right) collected CI values on a $5-\mathrm{cm}$ interval, and the penetration rate was controlled manually.

Data were collected in a $10 \mathrm{~m}$ by $6 \mathrm{~m}$ rectangular site inside a greenhouse (Fig. 2). The area was divided into $1 \mathrm{~m}$ by $1 \mathrm{~m}$ grid cells, and replicate CI profiles, 2 profiles with the commercial unit and 6 profiles ( 2 insertions $\times 3$ tips) with the 3 -tip prototype, were obtained from each cell. Spacing of the replicate measurements was about $20 \mathrm{~cm}$ around the center of each cell.

For the prototype CI profile data, different averaging 


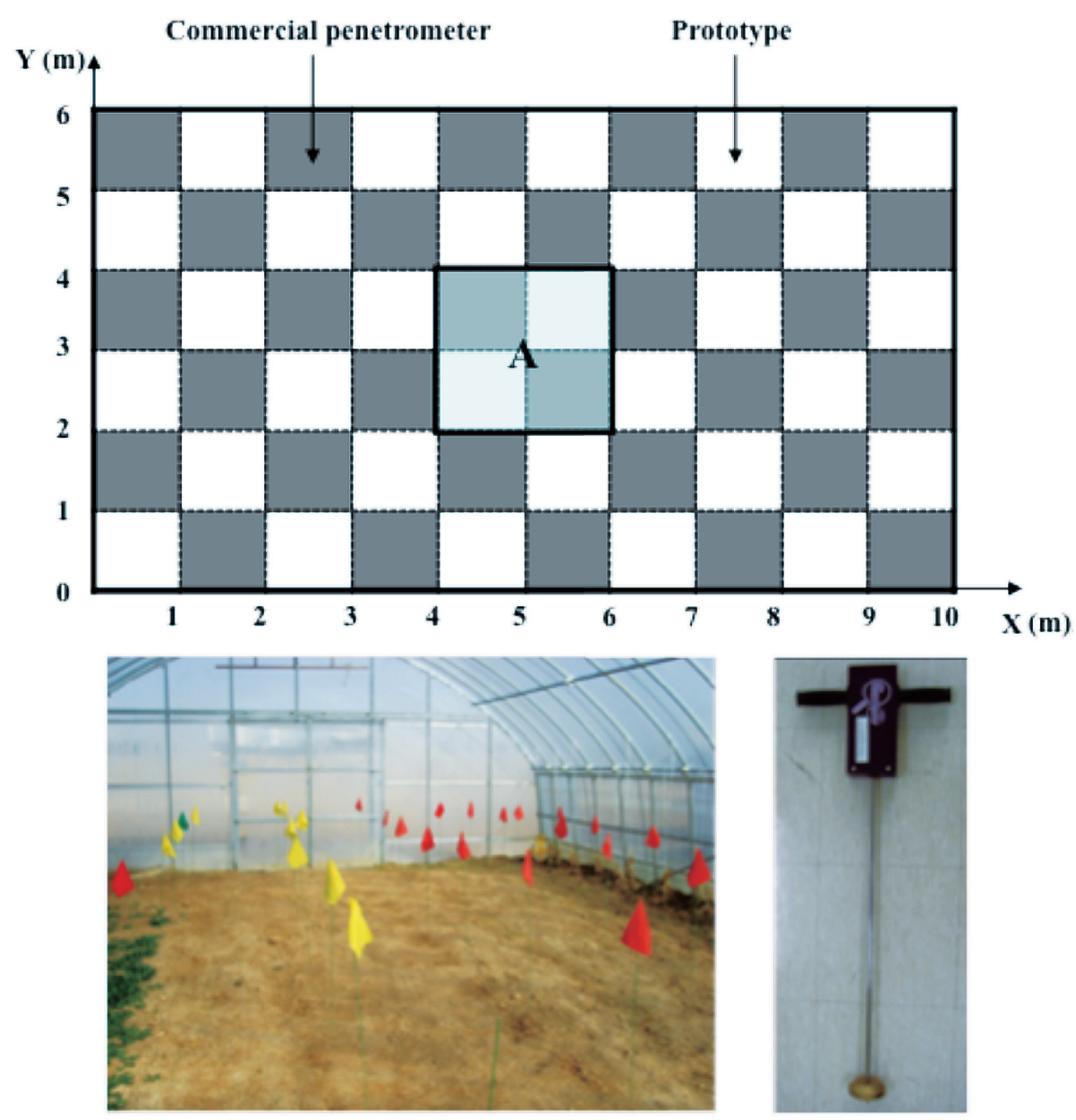

Fig. 2. Layout of CI data collection (top), photo of the experimental site (bottom left), and photo of the commercial hand-operated single tip cone penetrometer (bottom, right).

methods were examined by comparison to the commercial penetrometer data in the 4 adjacent cells (i.e., "A" area in Fig. 2). These were: 1) as collected, comparing 4 profiles from the commercial unit to 12 profiles from the prototype, 2) averaging the 3 profiles obtained with the prototype at each insertion to obtain 4 mean profiles for comparison to the 4 commercial-unit profiles, and 3) further averaging the data from method 2 with a 4-cm depth average centered at every $5 \mathrm{~cm}$.

Then, geostatistical analysis was conducted to compare nugget variances of the two datasets since nugget variance in a variogram would be due to measurement errors and micro-variability over distances smaller than the minimum distance between observations (Webster and Oliver, 1990). Kriged maps of the datasets were also compared.

Finally, a tillage recommendation map for a specific depth was generated based on the $2 \mathrm{MPa}$ criteria (Taylor and Gardner, 1963) to demonstrate possible application of the prototype sensor. Geostatistical analysis and semivariogram model selection were done with GS+ version 5.1 (Gamma Design Software, Plainwell, MI, USA). Mapping of kriged data was done with Surfer version 8 (Golden Software Inc., Golden, CO, USA).

\section{RESULTS AND DISCUSSION}

Fig. 3 compares CI profiles collected by the commercial hand-operated unit and the prototype motorized unit. When 4 CI profiles were compared (Fig. 3, left), CI patterns were similar up to about a 15-cm depth, but deviated at depths greater than that, with lower CI values for the prototype. CI profiles collected by the prototype seemed more reasonable since soils in the greenhouse would generally be more compacted near the surface and less compacted at greater depths. The nearly constant and higher CI values with the commercial unit may have been due to the effect of shaft friction created by contact of the penetrometer shaft with the edge of the hole during unstable manual insertion.

When the CI values were averaged for the 3 tips of the prototype (Fig. 3, center) and also averaged for 4-cm depth (Fig. 3, right), we obtained more stable data (i.e., less variability between CI profiles). Results indicated that, with the prototype motorized penetrometer, the time required to collected CI profiles could be reduced, the CI profiles represented actual soil strength levels better due to a stable penetration rate and angle, and the CI profiles were less erroneous (i.e., less variable).

Mean, standard deviation, and nugget variance of CI values collected by the commercial hand-operated unit 
C, MPa

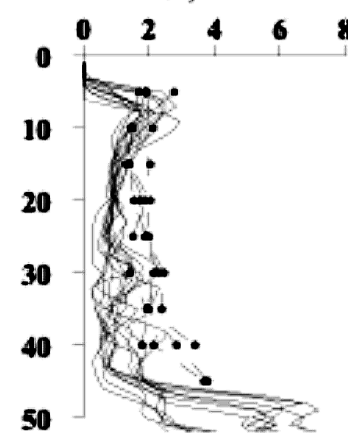

CI, MPa

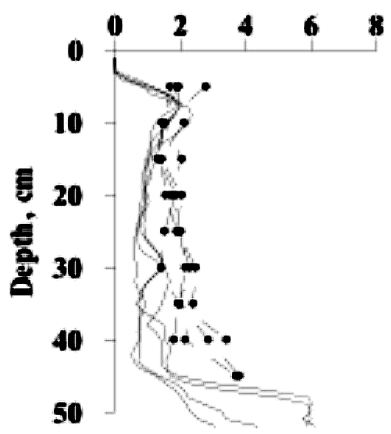

CI, MPa

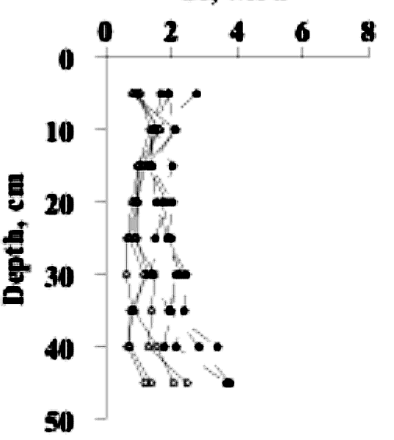

Fig. 3. Comparison of CI profiles collected with the commercial unit (dotted line) and the prototype (continuous line) in the four adjacent cells ("A" are in Fig. 2), applying three different averaging methods to the prototype CI profiles: no averaging (left, 12 profiles), averaging the 3 profiles of each insertion (center, 4 profiles), and 3-profile averaging and also $4-\mathrm{cm}$ depth averaging centered at every $5 \mathrm{~cm}$ depth (right).

Table 1. Mean, standard deviation (SD), and nugget variance of CI values collected by the commercial hand-operated unit and the motorized prototype

\begin{tabular}{cccc}
\hline Depth, cm & Mean, MPa & SD, MPa & Nugget variance, MPa \\
\hline Commercial unit & & & \\
\hline 5 & 2.28 & 0.48 & $0.23(\mathrm{~L})^{1}$ \\
10 & 1.71 & 0.42 & $0.16(\mathrm{~L})$ \\
15 & 1.63 & 0.40 & $0.12(\mathrm{~L})$ \\
20 & 1.78 & 0.46 & $0.15(\mathrm{~L})$ \\
25 & 2.01 & 0.53 & $0.25(\mathrm{~L})$ \\
30 & 2.15 & 0.68 & $0.38(\mathrm{~L})$ \\
35 & 2.97 & 1.16 & $0.81(\mathrm{~L})$ \\
40 & 3.33 & 1.06 & $0.42(\mathrm{~L})$ \\
45 & 3.92 & 1.05 & $0.90(\mathrm{~L})$ \\
Prototype & & & \\
5 & 1.57 & 0.51 & $0.21(\mathrm{~L})$ \\
10 & 1.06 & 0.33 & $0.05(\mathrm{~L})$ \\
15 & 0.79 & 0.19 & $0.02(\mathrm{~L})$ \\
20 & 0.75 & 0.15 & $0.01(\mathrm{~L})$ \\
25 & 0.98 & 0.25 & $0.06(\mathrm{~L})$ \\
30 & 1.27 & 0.30 & $0.07(\mathrm{~L})$ \\
35 & 1.75 & 0.75 & $0.03(\mathrm{~S})$ \\
40 & 2.58 & 1.32 & $0.00(\mathrm{~S})$ \\
45 & 3.59 & 1.20 & $0.39(\mathrm{~S})$ \\
\hline
\end{tabular}

${ }^{1}$ L: linear variogram model, S: spherical variogram model

and the motorized prototype were compared by depth, as summarized in Table 1. Mean values by depth showed that the commercial unit and prototype measured similar CI profile patterns overall, with a first peak at a 5-cm depth, a decreasing CI up to a 20-cm depth, and an increasing CI below that point.

Comparing SD values, however, indicated that CI values collected by the prototype were less variable than those by the commercial unit at many of the depths. Nugget variances were reduced significantly, indicating that measurement errors could be reduced, and possible structures of spatial CI variability at smaller distances (i.e., spherical model) were captured at 35-, 40-, and 45-cm depths with the prototype.

Kriged CI maps showed spatial and vertical variability in CI, indicating that presence of and depth to layers restricting crop growth were not the same over the entire area (Fig. 4). CI values obtained both by the commercial unit and the prototype were highest at a 40-cm depth. With the criterion of $2 \mathrm{MPa}$ suggested by Taylor and Gardner (1963), tillage was not recommended for most of the area up to a 30-cm depth using the data collected with the prototype, while some parts of the area were identified as compacted at many depths using the data with the commercial unit. This indicated that a false decision could be made and tillage labor and energy wasted through decisions based on potentially unstable and erroneous CI measurements. Using the CI data collected with the prototype, tillage was recommended for only $0.3 \%$ of the area at a $10-\mathrm{cm}$ depth (results not shown) and for $63 \%$ of the area at a $40-\mathrm{cm}$ depth (Fig. 5). 

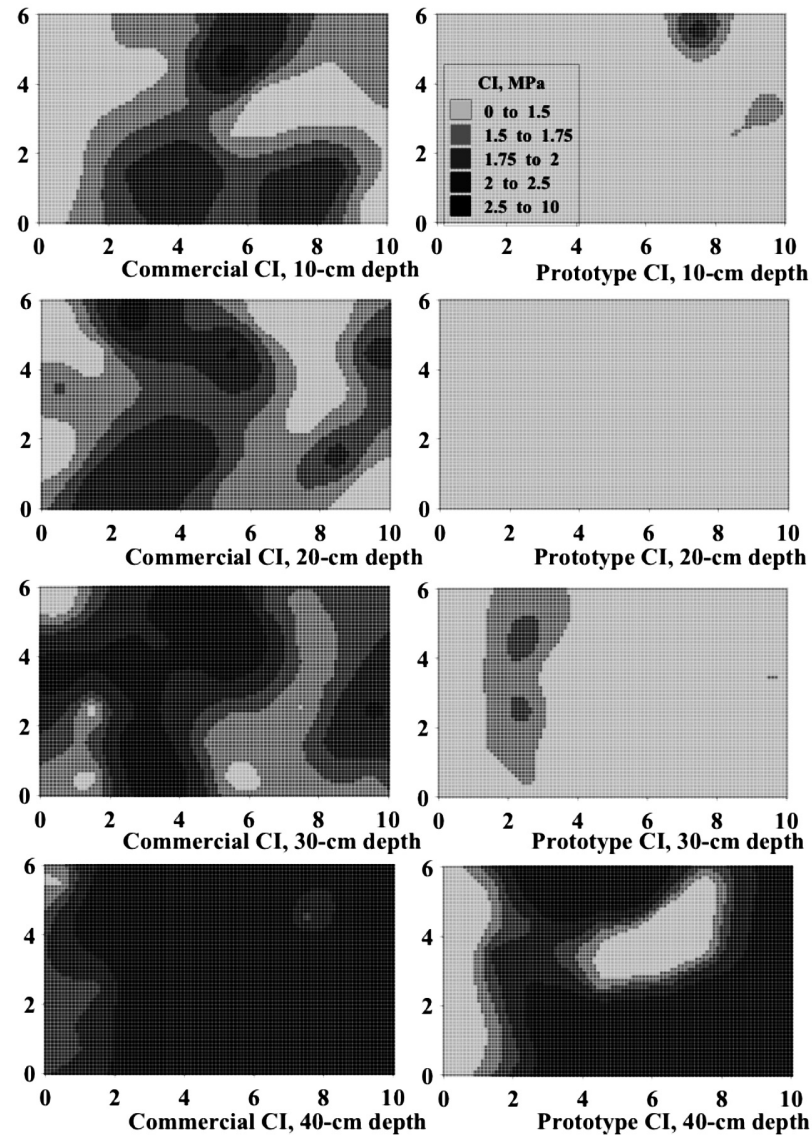

Fig. 4. Kriged CI maps at different depths obtained with the commercial unit (left) and the prototype (right). X-axis and Y-axis shows distance (m), this corresponds to Fig. 2.

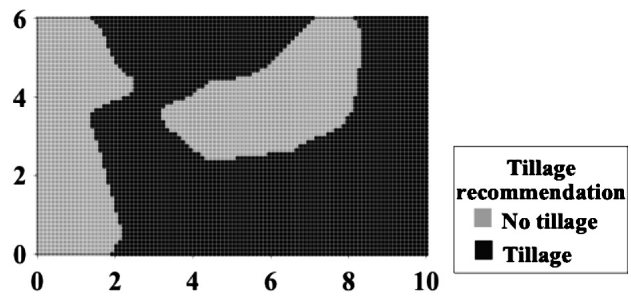

Fig. 5. Tillage recommendation map for the test area at a 40-cm depth. X-axis and Y-axis shows distance (m), this corresponds to Fig. 2.

\section{REFERENCES}

Andrade-Sanchez, P., S. K. Upadhyaya and B. M. Jenkins 2007 Development, construction, and field evaluation of a soil compaction profile sensor. Trans. ASABE, 50(3): 719-725

Barber, S. A. 1984 Nutrient uptake by plant roots growing in soil.
In "Soil Nutrient Bio-availability: A Mechanistic Approach", John Wiley \& Sons, Inc., New York

Canarache, A. 1991 Factors and indices regarding excessive compactness of agricultural soils. Soil Tillage Res. 19: 145164

Chong, B. H., Y. J. Park, H. K. Park. S. B. Park and K. U. Kim 2005 Mapping of cone index for precision tillage. J. Biosystems Eng. 30(2): 127-133

Chung, S. O., J. H. Sung, K. A. Sudduth, S. T. Drummond, and B. K. Hyun 2000 Spatial variability of yield, chlorophyll content, and soil properties in a Korean rice paddy field. In "Proceedings of the Fifth International Conference on Precision Agriculture", ed. by P. C. Robert, R. H. Rust and W. E. Larson, ASA, CSSA, and SSSA, Madison, Wisconsin, Unpaginated CD-ROM

Chung, S. O., B. H. Chong, S. Kang and G. Kim 2006 Application of sensors to assess soil conditions in a Korean paddy field. Key Engineering Materials, 321-323: 1213-1216

Chung, S. O. and K. A. Sudduth 2004 Characterization of cone index and tillage draft data to define design parameters for an on-the-go soil strength profile sensor. Agric. Biosystems Eng. 5(1): 10-20

Chung, S. O., K. A. Sudduth and J. W. Hummel 2006 Design and validation of an on-the-go soil strength profile sensor. Trans. $A S A B E, \mathbf{4 9}(1): 5-14$

Horn, R., H. Domzal, A. Slowinska-Jurkiewicz and C. Van Ouwerkerk 1995 Soil compaction processes and their effects on the structure of arable soils and the environment. Soil Tillage Res. 35: 23-36

Jo, I. S., J. N. Im, J. D. So, S. Y. Lee and D. U. Choi 1983 The effects of soil physical improvement on rice yield at fine textured Fluvio-Marine paddy field. J. Korean Soc. Soil Sci. Fert. 16 (2): 92-97

Kim, L. Y., H. J. Cho, S. O. Chung, W. Y. Park and K. S. Lee 2006 Determination of tillage depth based on physical properties of soil for rice production in Korea. Key Engineering Materials, 321-323: 1229-1232

Koolen, A. J. and H. Kuipers 1983 Agricultural Soil Mechanics. Springer-Verlag, Berlin, Germany

Lee, H. D., K. D. Kim, C. S. Kim and S. H. Kim 2002 Development of an automatic soil hardness measuring system mountable on agricultural tractors. J. Korean Soc. Agric. Machinery 27(6): 537-546

Mulqueen, J., J. V. Stafford and D. W. Tanner 1977 Evaluating penetrometers for measuring soil strength. $J$ Terramechanics, 14(3): 137-151

Price, R. R. and J. Theriot 2003 Development of a frame to automatically insert a hand-held penetrometer. ASABE Paper No. 031077. ASABE, St. Joseph, Michigan

Raper, R. L., B. H. Washington and J. D. Jarrell 1999 A tractormounted multiple-probe soil cone penetrometer. Appl. Eng. Agri., 15(4): 287-290

Taylor, H. M. and H. R. Gardner 1963 Penetration of cotton seedling taproots as influenced by bulk density, moisture content, and strength of soil. Soil Sci. 96 (3): 153-156

Webster, R. and M. A. Oliver 1990 Statistical Methods in Soil and Land Resource Survey. Oxford University Press, New York, NY. 